\title{
TELEVISION AND PUBLIC SERVICE IN THE UNITED STATES: WRITING THE HISTORY OF A PROBLEM
}

\author{
Anna McCarthy
}

New York University

\section{Abstract}

This essay analyses one of the most contentious topics in U.S. television studies: the conceptualization of public service in broadcasting. It gives a historical perspective of public service in broadcasting in the US and the political and ideological implications in the broadcasting of the programs and films.

Keywords: public television; broadcasting; audiences.

This essay offers some thoughts on one of the most contentious topics in U.S. television studies: the conceptualization of public service in broadcasting. First, some history. This concept, attributing a particular civic value to electronic communications, plays a key role in the development of both the medium of TV and the disciplinary matrices of television studies in the United States. Ostensibly, it is the philosophical and juridical foundation of all broadcasting infrastructures and institutions. The foundation was laid in the Radio Act of 1927, which

\begin{tabular}{|l|l|l|l|l|}
\hline Ilha do Desterro & Florianópolis & no 51 & p. 317- 338 & jul./dez. 2006 \\
\hline
\end{tabular}


established the essential features of the nation's radio and television broadcasting system. The contestation surrounding public service in broadcasting stems from this originary moment. As defined in the act, the concept of the public service was inextricably entangled with commerce, and with the moral and economic aspirations of American business leaders. The law drew on public utility law to define radio as an essential aspect of domestic life, akin to electricity and public water. ${ }^{1}$ Because of their essential role, broadcast corporations, like power and water companies, would be allowed to operate as restricted monopolies, with exclusive rights to the frequencies on which they broadcast. This arrangement, its advocates proposed, would best facilitate the delivery of services to consumers; the alternative, depicted as unlimited access to the airwaves for all, was pure chaos. This understanding of the best way to serve the public, as Tom Streeter has pointed out, encapsulates the corporate liberal philosophy underlying broadcast policy. Private business, many assumed at the dawn of broadcasting, was the sector of society most objective, efficient, and morally capable of handling the complex arrangements of the publicly owned airwaves, and providing the most benefits to the most people.

The broadcast corporation, as conceived in this period, was not simply a restricted monopoly. The restrictions imposed upon it by wise regulators, it was assumed, would ensure that acted as a benevolent monopoly. In exchange for the advantages of operating without competition, broadcasters' responsibilities toward the public were regulated in terms more substantial than corporations that encountered their customers in the free market. Specifically, as the Act spelled out in language characteristic of early twentieth century governance, those broadcasting companies federally licensed to operate on, and profit from, the publicly-owned resource of the electromagnetic spectrum must serve "public interest, convenience, and necessity" in their pursuit of profit. ${ }^{2}$ As critics, scholars, and reformists have often noted since this moment, this legal framework established electronic communication as a commercially based system and entrusted virtually exclusive use of the airwaves to private corporations. Ideals of public service were 
not necessarily admirable evidence of the altruism of capitalism. Rather, they were crucial elements of both public acceptance and limited government regulation of this system, so clearly weighted in favor of profitmaking enterprises.

But what exactly constituted the public interest, then and in subsequent decades? What kind of programming might count as public service programming? The answer has never been satisfactorily spelled out. Perhaps the most in-depth articulation of the meaning of public service was the one offered by the New Deal era policy document known as the Blue Book, written in 1946, twenty years prior to the formation of state-sponsored public television and networks known as the Public Broadcasting System. In this period, when all broadcast stations except for a small number of educational operators were commercially owned, public service was understood as an obligation met voluntarily by station managers. It was an obligation understood in terms of time as much as content. The idea was that local broadcasters would suspend the pursuit of advertising dollars for a few hours each week in order to provide disinterested coverage of political and cultural affairs. What this coverage might consist of was ultimately left to the discretion of station management.

This understanding of public service expressed utopian faith in the possibility of a technocratically managed rational public sphere, a faith rooted in early American ideals of republicanism and the myth of the virtuous citizen. ${ }^{3}$ The appearance of diversity was crucial to the fulfillment of this faith. Broadcasters were required to address the entire spectrum of possible interests and political positions represented in the audience, even those interests and positions held by only a few, and to provide a forum for the expression of multiple viewpoints on controversial matters. This implicitly minoritarian ethos of public service programming's commitment to diversity reflected a broader sense of connection between the viewing of these programs and the forms of activity that constituted full citizenship. If the audience of commercial programming was a collective of consumers, audiences for public service programming were 
seen as citizens (to the degree that the two categories are distinct in U.S. public policy and political speech). As the Blue Book explained:

In a sense a broadcasting station may be regarded as a sort of mouthpiece on the air for the community it serves, over which its public events of general interest, its political campaigns, its election results, its athletic contests, its orchestra and artists, and discussion of its public issues may be broadcast. ${ }^{4}$

With these laudable, if paternalistic, objectives in mind, FCC policy affirmed the authority of representatives of private interests to act as the trustees of public communications.

However, over the course of the next two decades, scandals over rigged quiz shows, combined with the growth of educational broadcasting and the increased competition among commercial networks to alter the landscape of public service broadcasting. Increasingly, in commercial networks the short, inoffensive "public service announcements" of the Advertising Council, a business group, came to dominate, while legislators, together with a coalition of nonprofit educational and community organizations and large foundations, worked to secure the passage of the 1967 Public Broadcasting Act that created PBS. The failure of commercial television to address viewers as citizens rather than consumers was one of the motivations for the creation of this state-funded public television system; the creation of this system, conversely, relieved networks of the obligation to do so. ${ }^{5}$ Implicit also was the idea that viewers themselves had failed, unable to integrate media consumption and civic life. State-sponsored TV, devoted to fostering citizenly duties, was needed to correct this situation. What did citizenship mean in state-sponsored television? As Laurie Ouellette notes, early PBS identified its mission as both a "quest to cultivate" cultural tastes and a form of neutral political education intended to promote rational civic reflection. ${ }^{6}$ In a sense, public television drew on ideals established in the Blue Book's characterization of public interest 
TV as programming was "better for" the audience than the commercial fare aimed at the lowest common denominator.

Television studies enter the picture at around this time, the product of social scientific and humanistic inquiry into mass media, both as forms of national communication among citizens and as evolving venues for artistic creation. ${ }^{7}$ Public service ideals, despite their failure in the context of commercial TV and their suspiciously elitist formulation in state-sponsored TV, were at the center of both these areas of inquiry. Although not always articulated in the language of citizenship, these ideals lay at the heart of reformist scholarship looking for ways to improve TV's offerings. As many argued, "trusteeship" model of public service, in which commercial broadcasters must act as public servants and, along with their audiences, participate freely in electronic version of the public sphere, has obvious shortcomings. ${ }^{8}$ Advocates of noncommercial networks argued over the course of the twentieth century that broadcasters consistently failed to give voice to the diverse viewpoints and noncommercial taste cultures imagined in the paternalistic designation of public interest. Media reform activists achieved significant victories over the decades, most notably in the 1960s, with the formation of PBS and the success of efforts to force the FCC to deny licenses to stations for their failure to fulfill their public interest obligations. ${ }^{9}$ But on balance, they had a limited impact. From a macro-perspective the public service mandate that technically still governs private broadcasting has not been consistently or effectively enforced. ${ }^{10}$ Indeed, there have been many significant defeats. During Ronald Reagan's presidency, the FCC dismantled its "fairness doctrine" that required broadcasters to air controversial programming, presenting both sides of every issue. The loss of the fairness doctrine was the destruction of a key component of basic models of broadcasting's public service obligations, not only in the United States but in many countries. Around the same time, the deregulation of broadcast ownership restrictions began, a process that continues to this day. The commitments to diversity, localism, and debate on which U.S. definitions of the public 
service in broadcasting were originally based have largely been eroded since the postwar years, part of a broader conservative effort to undermine New Deal-style models for regulating economic life and ensuring social wealth. If business in the corporate liberal era paid lip service to the idea that profit must be subordinated to the public service commitment (for a few hours a week, in airtime that no-one watched anyway), the present moment, governed by a political logic dubbed "neoliberalism" both at home and abroad, is one in which regulators argue that the logic of the absolutely free market is the best mechanism for ensuring that the public will be served.

So what does public service broadcasting look like today? At the time of writing the Bush administration has taken over the state-run public broadcasting system. For some leftist critics, this is an ironic state of affairs. After years of criticizing PBS for its corporate connections and fighting against federal defunding that might require further pacts with business, it turns out that the most serious threat to PBS's status as an "alternative" to mainstream commercial TV is not its reliance on corporate support but rather its status as a state-run system. ${ }^{11}$ Now administered by Republican ideologues, PBS is in the midst of a transformation from a lukewarm wellspring of liberal centrism into a clear channel for promoting the Right's policies.

Thus, at the moment in which I write, neither activism nor scholarly critique based on concepts of public service broadcasting in the U.S. are easy to sustain. Indeed, efforts to address the question of how the public might best be served by TV are fatally divided by tired antinomies (e.g. populism vs. elitism, cultural studies vs. political economy). ${ }^{12}$ The weakness of public service broadcasting and its marginalization within the commercial system has had an impact not only upon activist strategies of broadcast reformers but also upon the writing of scholarly histories of radio and television and the roles they have played in U.S. political culture. Scholars have tended to see public service as an imperiled and disappearing resource that must be defended from its corporate violators and, by extension, from the 
taint of popular culture. ${ }^{13}$ But although this diagnosis is undeniably accurate, it makes it difficult for histories written in this vein to acknowledge and address the rather suspect terms in which the concept of the public interest is couched. In other words, historians sympathetic to the democratic cause of activists must accept the reformist ideal of a pure public sphere, despite its suspect association with bourgeois enlightenment and all of its liberal exclusions. They must also believe that broadcasting is capable of activating this ideal and making it real if they are going to chronicle its decline and argue effectively for its rehabilitation. ${ }^{14}$

The problem with this approach, as Lynn Spigel notes, is that "clear-cut distinctions between public service and public relations, between education and commercialism, do not hold up."15 The importance of this point cannot be underestimated. When one looks at the history of programs that have been presented, and viewed, as public service programs, they are frequently saturated with commercialism in some form or another. Throughout the 1950s, for example, the National Association of Manufacturers distributed its filmed documentary series Industry on Parade as noncommercial public service programming, even though each program focused almost exclusively on particular consumer products. Because the series was intended to illustrate consumer product industry's contributions to the nation's economic and cultural wealth and turn public opinion against organized labor, rather than explicitly sell products, it could be considered a public service. The lack of separation between public service and commercialism has set a somewhat fruitless agenda for media critique and analysis, Spigel argues. As she suggests,

the growth of Television Studies at the dawn of the 1960s can be seen as an attempt to create a semantic order, a binary opposition between public service and public relations and between the opposing terms these two fields of discourse generate (binary oppositions like education vs. 
commercialism, information vs. entertainment, art vs. kitsch, interactive vs. passive." ${ }^{\prime 16}$

Television studies' attempt to define some programs as "good $\mathrm{TV}$," fullfilling the obligations of public service, and defining others merely as a betrayal of these obligations then is one of the significant historical processes that, Spigel notes, have ended up dividing various constituencies that study television from each other, such as journalists and television scholars with Ph.Ds. ${ }^{17}$

I agree with this assessment, but merely noting the existence of such divisions does not help overcome them. How do scholars find new ways to talk about public service? Is the concept of public service trapped in a potentially stultifying binary schema that offers critique and dismissal as the only alternatives to the idealism of broadcast reformers? ${ }^{18}$ Thomas Streeter has advocated one approach that to my mind has a great deal of potential. He suggests that we see public service as a discursive form rather than an empirically achievable reality. Its value for both progressive critics and corporate liberals is that "unlike competition, on its face the term 'public interest' suggests something noneconomic, something outside the bounds of private property and market exchange. ${ }^{\prime 19}$ This is an important insight, as it helps scholars locate the discourse of public service within particular historical and material circumstances rather than normative ideals of pure democracy. The debates and struggles over the question of how to achieve public service in broadcasting are, he notes, caught up in the broader contradictions of liberalism as a political philosophy, and corporate liberalism as its specific manifestation within the social-juridical discourse of the early twentieth century U.S. As Streeter shows over the course of his exhaustive study, the history of broadcast policy in the US

can be seen as an attempt, characteristic of twentieth century liberalism, to regain the footing lost in the shifting sands of one set of contradictions-the incoherence of atomistic individualism and of its industrial correlate, laissez-faire 
business principles-by shifting weight in the direction of another set of (equally contradictory) liberal principles-a faith in the power of expertise and objective scientific knowledge to make manifest a transcendent, reified 'public interest."'”20

Streeter's keen sense of historical change and political mobilization allows him to name public service as a discourse and beyond that, to look at how it is embedded as a discourse within institutional and juridical sites, how it emerges in language, how speaking positions are distributed within it, and most crucially, how it changes over time, in relation to historical forces external to broadcasting.

To see public service as a discourse in television, rather than an achievable possibility, is not to dismiss it or marginalize it as "not real," despite the fact that to name something "discursive" is often, implicitly, to give it the status of a "social construction." Reflecting on the debates for or against social constructionist arguments in the natural and social sciences, Bruno Latour points out that the focus on whether something is real or constructed prevents us from asking more interesting questions about techniques and practices: "is it well or badly constructed" vs "is it constructed or real?" Similarly, Foucault suggests that the appropriate questions to ask of a discourse don't concern its status as the utterance of a particular author but rather its diverse modes of existence: Where does it come from; how is it circulated; who controls it? What placements are determined for possible subjects? Who can fulfill these diverse subjects?"21 Rather than asking whether something does or does not perform a real public service, or whether a genuine and stable form of public service broadcasting is achievable, it might be better to ask "who or what is allowed to speak and act in the public service?" in who's name?" "to what end?"

For some, the answers to these questions will likely involve modern nexuses of power, agency, and knowledge like "capitalism" or "the liberal state," but naming these monoliths is not enough. The point for me is to understand the roles that concepts of public service television 
play in political culture of the nation. How do particular interests, at defined moments and trajectories of historical struggle, articulate themselves in popular media through concepts of public service? What political goals were served in the transformations of the variants of liberalism that intersected in the concept of public service television? Returning to Streeter's assessment of the concept's presence in changing notions of liberalism, we might ask how the shift toward technocratic understandings of the public interest that Streeter chronicles in the sphere of policy extend beyond the confines of the Federal Communications Commission and the offices of the networks and into the realm of everyday speech and the assumptions of citizenship. After all, the technocratic turn of which he writes did not occur in a political vacuum. It was itself surely shaped by determinations and conflicts taking place in other realms where citizenship was being debated and managed in the postwar history of the United States. It is important to look at how external concepts of the civic good might shape the more narrowly institutional ones that emerge in policy and industry.

What I am proposing, in short, is an historicist-materialist approach to the concept of public service in American commercial television, one that examines the political rationalities served by the concept in broader cultural contexts. This approach understands public service as a flexible discursive relationship between audiences, sponsors, and broadcasters, one that greatly exceeds the strict policy definition of the category as noncommercial programming. Rather than dismiss public service or uphold it as the as yet unmaterialized savior of the broadcasting world, we should look closely at what this impure and ill-defined concept has achieved, and what interests it has served-interests far more concrete and locally-articulated than the imaginary notion of the public. There is ample evidence that the modes of citizenship envisioned in particular instances of public service television are hardly democratic. Stephen Classen, for example, has shown how White segregationist groups produced public service programming on the local level throughout the 1950s, 
working with sympathetic station managers to legitimize and add respectability to the views of "White Citizens' Councils" active in Southern state politics in the 1960s. ${ }^{22}$ Citizens' Council Forum, widely distributed to stations for airing in the required weekly allocation of noncommercial public service broadcast hours, used iconography and rhetoric designed to recall the visual and verbal forms of "educational, value-neutral" debate. The program began, he notes,

with a graphic logo of American and Confederate flags crisscrossed and encircled by the words 'state's rights, racial integrity.' One of its standard ending segments announced: 'We Americans are threatened with the loss of many of our hard won freedoms: the historic right of each sovereign state to govern itself without interference from political courts; the right of the individual to choose his associates without the prodding of federal bayonets, and the right of each citizen to make up his mind in the American way, free from propaganda.'

Here, the liberal language of civility, freedom, and equality is implemented in the service of a cause that is none of these things.

Of course, one could look at this example from the idealist perspective. The visual use of flags, a motto, and the heraldic motif of crossed symbols, coupled with the civic speech asserting the liberal ideals of the sovereign subject, could be seen as a co-optation of the pure notion of civic discourse, its perversion by anti-democratic forces. But it is not clear that such a civic norm has ever been achieved. Rather than claim its existence and measure everything against it, I am advocating an approach that asks what particular assertions of the civic norm achieve. Who gets to speak in the voice of public service television? Citizens' Council Forum illustrates the extreme range of agendas that have laid claim to the idea of television as a venue for teaching citizenship, and promoting certain ideas about what civic life and national identity might be. It suggests, moreover, that it is impossible to see the concept in politically unmarked terms, as a means by which 
television allows citizens to make "rational choices" that maximize their interests and those of the nation.

Along with this proposed focus on the goals of particular efforts to speak in the public service voice, it is equally important to take into account obstacles to these goals. In the language of liberal governance, we might say that it is important that the study of public service broadcasting look not only at "political rationalities" but also at their "messy implementation." ${ }^{23}$ Focusing on the former, we can easily discover a discourse aimed at the production of a viewing citizen-subject encountering television as a benevolent civic force teaching the rights, freedoms and responsibilities of citizenship in all its economic, cultural, and (geo)political dimensions. But focusing on the implementation of this ideal we might see a very different set of conflicts and tensions playing out. Among other things, this brings into the picture not only those who succeed at speaking the televisual language of citizenship, but also those who fail, inviting us to explore the question of what agendas do not succeed in finding a public service voice, and why.

These questions are particularly interesting when posed in relationship to the postwar period, a period leading up to the establishment of PBS. Within the institution of TV, it was the last gasp of the corporate liberal model of commercial television as a civic entity and a trustee of the public interest. In U.S. history, it was a period when civil rights protests, globalizing international business entangled with a large but embattled domestic labor movement, and the Cold War made the question of citizenship particularly crucial. As a result, the production of public service TV was a pedagogical opportunity that many political groups and constituencies sought for themselves. All kinds of organizations worked hard to produce broadcast material that presented itself as public service television. The common thread uniting the range of institutional relations and aesthetic forms that comprised this material is their manifest articulation, at once moral, epistemological, and generic or aesthetic, of an approach to sponsorship and programming that goes beyond "mere" entertainment and for that matter the singleminded pursuit of profit in order to pursue loftier goals. 
Let me conclude with two examples from the archives of public service programming in this period, chosen because I think they communicate and make concrete the value of historical research on the rules and conventions governing public service television as a form of discourse. Both concern the civil rights movement; one is from the period when the sponsorship of television programming addressing the question of desegregation in the Southern states was just emerging as a matter of national debate in the mass media, the other from the late 1960s, when media coverage of race relations stressed growing "civil unrest." Both examples reveal a great deal about the ways that broadcasters understood the effects of television images within political culture, and the limits they placed on such images. Although national television executives were mostly liberals from the Northeast states, in the mid-1950s they were reluctant to air programming that overtly criticized Southern states, partly because they did not want to alienate White audiences in these states, and partly because they did not want to find themselves bound by the Fairness Doctrine to give equal time to segregationists to present their point of view on the topic of whether or not civil rights was a legitimate movement and whether desegregation of schools and public facilities should occur in the South. ${ }^{24}$ As a result of this self-serving hesitancy on the part of broadcasters, sponsors seeking to promote civil rights causes through unpaid public service time encountered great difficulty getting access to the airwaves.

Using archival sources, it is possible to reconstruct the contexts in which civil rights sponsors presented their views to networks and justified their request for donated airtime. In the response, we can see how broadcasters maintained and justified their position of neutrality and how they offered alternatives to direct advocacy in their understanding of the public service in relationship to civil rights. On the most manifest level, such programs were an attempt to govern conduct and ideas by talking to the mass audience as a collectivity composed of "black" and "white" citizens. Less obviously, but more crucially for understanding public service television as an arena of rule, they were also as an opportunity for white people in power to talk 
to each other about how to negotiate the enfranchisement demands of Black U.S. citizens. The films and broadcasts that did eventually air reflected the input of any number of intermediaries, each with their own agendae and investments in particular modes of representation, including those cultural workers who produced these programs for sponsors and broadcasters who authorized their airing. The conversations that took place around public service sponsorship therefore reveal a great deal about the relations of power channeled within it.

The first of my two examples is drawn from the files of a liberal philanthropic organization called the Fund for the Republic, which deposited its papers in the Public Policy archives at Princeton University. The second is drawn from the University of Illinois's archive of the papers of the Advertising Council, a voluntaristic organization that articulated its postwar mission as the creation of a positive image of the advertising industry and business in general, and which is perhaps the most prominent voice of public service advertising in commercial broadcast television. The negotiations surrounding representation and viewership that surrounded these programs allow us to see the inscribed viewer-citizen of public service programming as the product of multiple intersecting governance ideals, and understand how some representational strategies endured while others did not.

In the case of the Fund for the Republic, what we see is the inflexibility of the well-intentioned liberal elites in their support for civil liberties and civil rights. The program in question was the first television project developed by Fund officers, who pitched it to NBC in 1954. A filmed pilot for a series focused on incidents of prejudice in American life, the program idiosyncratically presented acted sketches illustrating common situations in which prejudice might occur. It interspersed these sketches with "humorous" commentary by cartoonist Al Capp, whose task was to point out the absurdity and illogic of discrimination to the viewer. The Fund screened the program for NBC president Sylvester "Pat" Weaver with high hopes. But Weaver's 
response was less than positive. Summarizing the meeting in a memorandum to Fund officer W.H. Ferry, a staff member reported that he reacted with utter distaste, questioning both the humor and the direct treatment of racism. The memo further noted that Weaver explained that the program went against NBC's policy for racial representation, which he described as combating discrimination by using "Negro actors wherever they should be used without any emphasis on the actual fact of their use." ${ }^{25}$ Needless to say, the show was not picked up by the network.

Moments such as this offer illustrate the very different degrees of comfort with popular culture as a whole that elites brought to public service television. Weaver's concern with the advisability of adopting such a didactic voice reflected his nuanced, professional sense of the audience and its receptivity. If the Fund saw viewers as open vessels for ideology, Weaver saw the audience as recalcitrant and ultimately resistant to lectures from above. His response is instructive in highlighting both the manifest differences and the underlying similarities between the liberal sensibilities of representational policy at the networks and the assumptions of the Fund's officers. Both groups believed that setting examples was a crucial mechanism for civic pedagogy in TV, but their sense of the effects of these examples were wildly different. In Weaver's view, social change was best effected through the unremarkable representation of black people. The unstated, and pathologizing, assumption in his policy was that such treatment would normalize them in the white mind. Fund officers, on the other hand, sought to set examples in the realm of behavior, seeking to normalize liberal attitudes rather than particular populations in the minds of the average white viewer.

This points to the basis of the Fund's understanding of the relationship between television viewing and civic action, an understanding that its officers refused to relinquish despite consistent challenges from industry professionals. ${ }^{26}$ The Fund officers assumed a television viewer for whom the divestment of prejudice was a matter of rational choice. Television's task was to motivate that choice by illustrating its benefits as a social good. This image of the viewer fully 
capable of disinterested reflection on action was in keeping with the Fund's goal of reactivating the principles on which the American Republic was founded. Indeed, when Fund officers saw problems in their projects, their judgments rested on how the program appeared to activate this enlightenment in themselves. Although they were highly scornful of popular culture, Fund officers could only conceive of the television viewer a rational liberal subject who, like Hoffman himself, was fully aware of the social costs of prejudice. Unable to resolve these contradictory understandings of medium and viewer, the Fund failed to get most of its projects on the air.

In contrast to this view of television as an instruction manual for rational civic activity based on negative examples, the Advertising Council's television activities addressed a viewer as a member of a locality, rooted in daily interactions. After the 1965 passage of the landmark Voting Rights Act the Council launched a campaign to promote "better race relations." The civic model on which this campaigns rested, like campaigns on other matters such as mental health awareness, economic security, and public safety, was the ideal of community self-management (rather than government regulation). Indeed, despite the legislative context surrounding its launch, the campaign did not take voting as its model of civic participation. Rather, it focused on such voluntaristic community structures as "bi-racial committees." As the Council's chairman told the Association of National Advertisers, the Council drew its mandate from conversations with Black Americans about their relationship to Whites:

The predominant attitude of Negroes, we were told, is one of frustration arising from the feeling that no-one wants to do things with Negroes, although many whites want to do things for Negroes. Yet experience has already shown that if Negroes and Whites will only sit down together and discuss their community's racial problems, they can usually be alleviated or solved. ${ }^{27}$ 
The campaign thus began on a basis not dissimilar to that of the Fund for the Republic, in that it sought to reform civic behavior through television. Yet the interpersonal focus, offering concrete solutions within a civic framework outside of the traditional mechanisms of the state, appealed to the viewer as a participant in, rather than a judge of, everyday racial interactions.

This sensitivity to context extended into the profess of refining the representational strategies of these programs. The Council showed a print of one civil rights-based public service announcement to the representatives from labor, civil rights, and philanthropy whom it invited to serve on its Public Policy Advisory Committee, the body that approved "controversial" campaigns before they aired. The minutes of these meetings indicate that dialogues addressed the problems of identification and inclusion involved in representing the process of interracial exchange. Labor leader Joseph Beirne noted that the film would annoy black viewers because "the camera did not focus on the Negro when he was speaking." This remark not only helped pinpoint the need for reediting; it also became an occasion for the sharing of white resentment. Helen Hall, a prominent social worker, supported Beirne's observation by noting, in what reads today as an aggrieved tone, that this detail was important because "it was not possible these days to have a Negro group visit any establishment without having them count the number of Negroes on the staff, and look to see whether they were being treated with the same degree of courtesy and importance as the whites. ${ }^{\prime 28}$ The committee meeting here serves as a venue for white complaint and also, begrudgingly, the accommodation of Black critique in the formation of a public service address.

For leftist critics and historians, what is important about these dialogues on visibility, community, and respect that The Advertising Council officers carried out, especially when compared with the failures of the more socially liberal Fund for the Republic, is the degree to which the process of devising their public service programs reflect the articulation of civil rights with the broader neoliberal program of the organization. The Advertising Council was a pro-business, anti- 
regulation organization, formed as a public relations effort to promote the benevolent image of advertising as an industry and the corporate sector in general. Its agenda took shape not via the crudely propagandistic lectures preferred by many business groups, but rather through rhetorics of personal responsibility. ${ }^{29}$ Whereas progressive voices like the Fund for the Republic failed to gain access to television as a medium of governance in part because of their preaching tones and ill-formed models of viewership, the corporate activists of the Advertising Council, for whom civil rights was merely a pretext for advancing claims of corporate citizenship, were able to successfully occupy the enunciative position of fair-minded, neutrality that public service broadcasting promised.

The foregoing examples have, I hope, foregrounded the operations of public service as a discourse in U.S. television, illustrating the political work performed through various forms of civic speech on TV. Looking at the representation of the civil rights effort in public service television not as a clear-cut process that can be assessed by counting the number of broadcast hours devoted to it but rather as a very murky process of negotiation, one in which interests unrelated to civil rights (e.g. the promotion of benevolent corporate citizenship) are most successful in finding expression in the public service format. I hope that they have also countered abstract-normative notions of what the public service is or should be with a historical-material alternative, namely, archival research. Archival collections allow the media historian to put the public service films of early TV into genealogical perspective, enabling us to traceagainst the often depthless obviousness of the texts themselves-the forms of alterity and conflict that shaped project of governing by television in the postwar period. As competing sectors of political culture sought access to the enunciative position of public service in broadcasting, they negotiated with other elites and struggled to incorporate on their own terms the perspectives of various groups they considered their other. Obviously, the availability of archival materials varies considerably within and between particular national 
contexts, and researchers outside the U.S., interested in other forms of televisual governance, might find a very narrow array of options when they try to follow archival leads. Hopefully, in laying out a set of discoveries from my own work in terms of broader questions of how we might read the final inscription of audiences and modes of address in particular texts, the foregoing discussion has at the very least opened up useful analytical pathways for those researchers who find that their access to the civic imaginary of public service television begins and ends with the visual text.

Notes

1. See Public Service Liberalism.

2. SeeStreeter and others on corporate liberalism. On early twentieth century statecraft, see "associational state." Article.

3. See Michael Warner, "Letters of the Republic", for a full discussion of the republican ideals of publicity. For a critique of public service broadcasting policy along similar lines, in the context of British, European, and Australian systems, see 1.

Elizabeth Jacka, "Democracy as Defeat: On the Impotence of Arguments for Public Service Broadcasting." Television and New Media, 2003. 4(2): p. 177-191. See also the discussion of the behavioral and affective presumptions of the rational public sphere as a model for the Public Television System's civic role in the late 1960s in Laurie Ouellette Viewers Like You? How Public Television Failed the People. New York: Columbia University Press, 2002.

4. The Blue Book, reprinted in Frank J. Kahn, Documents in American Broadcasting. Englewood Cliffs, N.J.: Prentice Hall, inc., 173.

5. Ouellette, 113.

6. Ouellette, chapter on cultivation.

7. Spigel, making of a TV literate elite.

8. For an early articulation of these limitations, see "Smythe Scientific American" essay. 
9. The most notable of these cases involved the racist, segregationist programming on WLBT in Jackson, Mississippi in the Civil Rights era. See Classen, Watching Jim Crow.

10 As Thomas Streeter notes, "The FCC's theoretical power under public-interest clause to engage in after-the-fact regulation of existing stations has produced much storm and fury and a few Supreme Court cases, but has had very little impact on the overall character of American broadcasting." See his Selling the Air: A Critique of the Policy of Commercial Broadcasting in the United States . Chicago: University of Chicago Press, 1996.

11. Newt Gingrich's failed attempt to "zero out" public broadcasting funding in the 1990s was innocuous in comparison to the right wing assault taking place today.

12. Jacka, Hartley, Garnham, Sconce.

13. See "McChesney" for an example of scholarship in this vein.On the rejection of the popular in the founding of American state-funded public service broadcasting systems see Laurie Ouellette People Like You? How Public TV Failed the People. New York: Columbia University Press, 2002.

14. McChesney?

15. Spigel, Ibid.

16. Spigel, L., "The Making of a TV Literate Elite" in The Television Studies Book, Christine, Geraghty and David Lusted, Editors. Arnold: London, 1998, 72. For a similar critique of purist approaches to public service, see Sconce, "See You in Hell, Johnny Bravo." Sconce's Swiftian argument is that the animated "reality" program Celebrity Death Match, in depicting the rich elite class as objects of scorn and abjection, performs a far more vital public service than the serious-minded educational programs that generally fall into that category. This point is a useful polemic in the earnest and elitist intellectual atmosphere of policy discourse. Yet although I appreciate Sconce's skepticism regarding the pieties of prosocial programming, I find the argument does not account for the ways that such programs enforce racial and gendered hatreds even as they propagate a vibrant class resentiment. The example that comes to mind for me is the moment in the British version of "I'm a Celebrity, Get Me Out of Here" when viewers voted to see Black boxer Nigel Benn tied to a tree for the night. It seems quite likely that for some "voters" the point was not the class-based satisfaction of seeing a wealthy celebrity 
humiliated, but rather of seeing it happen to a Black man. See Jeffrey Sconce, "See You in Hell Johnny Bravo," in Reality TV: Remaking TV Culture, L. Ouellette and S. Murray, Editors. New York: New York University Press, 2004.

17. Spigel, Ibid., 83.

18. See Streeter on neoliberalism and computer culture for more on why this isn't a good goal in itself.

19. Streeter, Ibid., 186.

20. Streeter, 10. On this point, see also Jacka.

21. Michel Foucault, "What is an Author?," in Language, Counter-Memory, Practice. Donald Bouchard, Editor. Ithaca, New York: Cornell University Press, 1977.

22. Stephen D. Classen, Watching Jim Crow: The Struggles Over Mississippi TV, 19551969. Durham, N.C.: Duke University Press, 2004.

23. These terms, and the relationship of ideal to reality implied here, are from Pat O'Malley, P., L. Weir, and C. Shearing, "Governmentality, Criticism, Politics" Economy and Society, 1997. 26(4): p. 501-17.

24. Torres.

25. Edward Reed Memo to Ping Ferry, January 9, 1954. Box 108 Folder 5., Fund For the Republic Papers, Seeley Mudd Library, Princeton University.

26. Instances of the rejection of professional advice can be found in these documents: $\mathrm{H}$. Hoffman's handwritten response on covering page of memo Edward Reed to Hoffman 1/26/56, Box 109 Folder 4., Schuebel Critique, 3/28/55, Box 108 Folder 8.

27. Edwin W. Ebel, presentation to the Association of National Advertisers, May 11 1965. 113/2/207 Historical File Folder 1230. Advertising Council Archives, University of Illinois Library.

28. "Report of the Public Policy Committee Annual Meeting, November 10, 1965." 13/2/209 Public Policy Committee Box, no folder number.

29. See David L., Paletz, Roberta E. Pearson, and Donald L. Willis. Politics in Public Service Advertising on Television. New York: Praeger, 1977. Perhaps the most 
notorious example of this use of public service is the Keep America Beautiful Campaign, sponsored by bottling companies, which promoted community-based solutions to littering (as opposed to government-imposed bottle deposits).

\section{References}

Classen, Stephen D. Watching Jim Crow: The Struggles Over Mississippi TV, 19551969. Durham, N.C.: Duke UP, 2004.

Foucault, Michel. "What is an Author?" Language, Counter-Memory, Practice. Ed. Donald Bouchard. Ithaca, N.Y: Cornell UP, 1977.

Jacka, Elizabeth. "Democracy as Defeat: On the Impotence of Arguments for Public Service Broadcasting." Television and New Media 4 (2003): 177-91.

Jeffrey, Sconce. "See You in Hell Johnny Bravo." Reality TV: Remaking TV Culture. Eds. Laurie Ouellette and Susan Murray. New York: New York UP, 2004.

Kahn, Frank J. Documents in American Broadcasting. Englewood Cliffs, N.J.: Prentice Hall, 1984.

O'Malley, Pat, Lorna Weir, and Clifford Shearing. "Governmentality, Criticism, Politics." Economy and Society 26 (1997): 501-17.

Ouellette, Laurie. Viewers Like You? How Public Television Failed the People. New York: Columbia UP, 2002.

Paletz, David L., Roberta E. Pearson, and Donald L. Willis. Politics in Public Service Advertising on Television. New York: Praeger, 1977.

Spigel, Lynn. "The Making of a TV Literate Elite." The Television Studies Book. Eds. Christine Geraghty and David Lusted. London: Arnold, 1998.

Streeter, Thomas. Selling the Air: A Critique of the Policy of Commercial Broadcasting in the United States. Chicago: U of Chicago P, 1996. 